\title{
Molecular detection of a virus, Pilchard herpesvirus, associated with epizootics in Australasian pilchards Sardinops sagax neopilchardus
}

\author{
Melanie Crockford ${ }^{1, *}$, John B. Jones ${ }^{1}$, Mark S. J. Crane ${ }^{2}$, Graham E. Wilcox ${ }^{3}$ \\ ${ }^{1}$ Department of Fisheries Western Australia, PO Box 20, North Beach, Western Australia 6920, Australia \\ ${ }^{2}$ CSIRO Livestock Industries, Australian Animal Health Laboratory, Geelong, Victoria, Australia \\ ${ }^{3}$ Murdoch University, South Street, Murdoch, Western Australia 6150, Australia
}

\begin{abstract}
In 1995, and again in 1998, high mortalities of pilchards Sardinops sagax neopilchardus were seen over their entire geographical range on the Australian coastline. A virus with typical herpesvirus morphology was identified as the causative agent, although the source of the virus remains unknown. At the time of the mortality events, the only available diagnostic test available for the detection of the virus was electron microscopy and hence, development of a rapid diagnostic test for detection and identification of the virus was required. Initial sequence data for Pilchard herpesvirus (PHV) was acquired by comparing the highly conserved region of the ORF 62 gene of other piscine herpesviruses (Ictalurid herpesvirus 1 [Channel catfish virus, CCV] and Salmonid herpesvirus 2 [Oncorhynchus masou virus, SaHV2, OMV]), and designing primers that successfully amplified a fragment of PHV. Here we describe the use of polymerase chain reaction (PCR) technology to detect PHV in infected tissues. Sequence analysis of amplified fragment resulting from this PCR is different from all known herpesviruses and can therefore distinguish PHV from all known viruses.
\end{abstract}

KEY WORDS: Pilchard herpesvirus $\cdot \mathrm{PHV} \cdot$ Polymerase chain reaction · ORF $62 \cdot$ Sardinops sagax neopilchardus $\cdot$ Sardines

\section{INTRODUCTION}

Between March and September 1995, high mortalities of pilchards Sardinops sagax neopilchardus occurred over their entire geographical range in Australia-over $5000 \mathrm{~km}$ of the Australian coastlineand also along over $500 \mathrm{~km}$ of the New Zealand coastline (Whittington et al. 1997). The Australian epizootic moved progressively, in a 'bush-fire-like' manner against the prevailing Leeuwin and East Australian currents (Griffin et al. 1997), at a rate of approximately $21 \mathrm{~km}$ per day to the west and $40 \mathrm{~km}$ per day to the east (Murray et al. 2000) with a point of origin in South Australian waters. Only adult pilchards (>11 cm length) were affected and no other species, including predators, were involved (Gaut 2001). It is estimated that in Western Australian waters at least $10 \%$ of the pilchard population were killed during the epizootic, however this figure was most likely underestimated as divers recorded many fish sinking to the sea floor soon after death (Whittington et al. 1997). The estimated loss to the Australian pilchard fishery after the 1995 epizootic was approximately Aus\$12 million (Gaut 2001).

Significant lesions were confined to the gills and comprised acute to subacute inflammation, followed by epithelial hypertrophy and hyperplasia (Whittington et al. 1997), presumably leading to death by asphyxiation. Following investigation, a herpesvirus was found to be consistently present in gills of affected fish and absent from unaffected pilchards (Jones et al. 1997), including fish sampled ahead of the mortalities as well as surviving fish sampled after the mortalities had ceased (Fletcher et al. 1997). Several hypotheses for disease introduction or emergence and transmission have been proposed but are still inconclusive (Jones et al. 1997). 
A second mortality event began in October 1998 (Gaut 2001), again in South Australia, and spread throughout the Australian pilchard range by mid-1999 (Murray et al. 2001), again involving high mortalities and the presence of herpesvirus in the gills of diseased fish, although on this occasion the mortalities appeared to be higher and the affected pilchards included a small number of juveniles. The spread of the mortalities was much slower in 1998/9, but higher mortality rates were observed, particularly in Western Australia, where an estimated $70 \%$ of the pilchard population on the south coast died (Gaughan et al. 2000), resulting in a severe depression of Australian pilchard stocks. The effects of these mortalities on other species were not directly studied, but an increase in mortality and decrease in breeding success of little penguins Eudyptula minor in 1995 in Victoria, was linked to the 1995 pilchard mass mortality (Dann et al. 2000). Other species are likely to have been affected (Gaut 2001). Subsequent to this epizootic no further disease outbreaks have occurred. Clearly, there is a need for an understanding of how this virus entered Australian waters and caused such devastation. It has been hypothesised that the virus was introduced into Australian waters through either bait imports or ballast water (Jones et al. 1997). If so, methods to detect subclinical infections in pilchard populations both in Australia and elsewhere are required. This paper describes a specific PCR to detect Pilchard herpesvirus (PHV) in clinically infected pilchards.

\section{MATERIALS AND METHODS}

Primer design. The first sequence data of the PHV genome was obtained using universal fish herpesvirus primers, designed to amplify approximately $400 \mathrm{bp}$ of fish herpesvirus DNA from the ORF 62 gene, in a PCR to amplify PHV DNA (Eaton et al. 2002). From this initial sequence, primers PHV373F, designed at the Department of Fisheries Western Australia, and PHV367R, a sequence supplied by CSIRO Livestock Industries, Australian Animal Health Laboratory in Geelong, Victoria, were developed to target only PHV.

Samples used. The main sample used for obtaining original sequence data was partially purified PHV from the 1995 outbreak. Samples used for sequence data comparison between the 1995 and 1998 outbreaks are listed in Table 1. Each of these samples from Table 1 were gill from the various fish tested, extracted using DNAzol (Life Technologies). Gill has consistently demonstrated pathological changes associated with disease and is the tissue in which virus has been visualised by electron microscopy, and from which virus has been successfully isolated. Therefore, gill was con-
Table 1. Sequence comparison of Pilchard herpesvirus isolates from 1995 and 1998 to the Pilchard herpesvirus reference sequence. NSW: New South Wales; WA: Western Australia; $\mathrm{NZ}=$ New Zealand

\begin{tabular}{|lc|}
\hline $\begin{array}{l}\text { Samples from } \\
\text { PHV-affected fish }\end{array}$ & $\begin{array}{c}\text { Sequence similarity } \\
\text { with reference strain }\end{array}$ \\
\hline 95-4420 (NSW) (1995) & $100 \%$ \\
Nelson Beach (WA) (1995) & $100 \%$ \\
Bay of Islands (NZ) (1995) & $100 \%$ \\
Smith's Beach (NSW) (1998) & $100 \%$ \\
FH/218 F Garden Island (WA) (1998) & $99.7 \%$ \\
FH/218 A Esperance (WA) (1998) & $100 \%$ \\
\hline
\end{tabular}

sidered to be the best tissue to use for this study. Further studies will involve the testing of various tissues for the presence of $\mathrm{PHV}_{i}$ however, for this study it was necessary to use the tissue most likely to give a successful result.

Preparation of partially purified virus. For sequencing, one of the samples used was PHV from the 1995 outbreak, detected by electron microscopy and partially purified by sucrose gradient centrifugation before being stored at $-80^{\circ} \mathrm{C}$. The partially purified virus preparation was resuspended in $100 \mu \mathrm{l}$ of digestion solution $\left(10 \mu \mathrm{l}\right.$ of $2 \mathrm{mg} \mathrm{ml}^{-1}$ Proteinase $\mathrm{K}$ in $100 \mu \mathrm{l}$ of sterile Milli-Q [MQ] water), allowed to digest overnight at $37^{\circ} \mathrm{C}$ before being heated to $80^{\circ} \mathrm{C}$ in a heating block (Ratek Dry Block Heater, Scot Scientific) for $20 \mathrm{~min}$, and then stored at $-20^{\circ} \mathrm{C}$.

Modified DNAzol extraction procedure. A tissue sample (while still thawing) of 25 to $50 \mathrm{mg}$ was added to a $1.5 \mathrm{ml}$ microcentrifuge tube containing $0.7 \mathrm{ml}$ of DNAzol reagent (Life Technologies), homogenised using a hand-held disposable pestle (Scientific Specialties) and centrifuged at $10000 \times g$ for $10 \mathrm{~min}$ at ambient temperature. The supernatant was transferred to a fresh microcentrifuge tube, and $0.5 \mathrm{ml}$ of $100 \%$ ethanol (Sigma) was added. The tubes were inverted several times to allow a precipitate to form, before being centrifuged at $10000 \times g$ for $5 \mathrm{~min}$ at ambient temperature. The supernatant was decanted, leaving a visible pellet at the bottom of the tube. The pellet was washed twice by resuspending the pellet in $0.7 \mathrm{ml}$ of $75 \%$ ethanol, centrifuging at $10000 \times \mathrm{g}$ for $5 \mathrm{~min}$ at ambient temperature and decanting the supernatant after each wash. Any remaining ethanol was removed using a pipette, and the pellet was allowed to dry on a heating block at $50^{\circ} \mathrm{C}$. Sterile water (Astral Scientific) was added to the DNA and the tube was placed on a heating block at $55^{\circ} \mathrm{C}$ for up to $1 \mathrm{~h}$ to resuspend the DNA. The concentration of the DNA sample was determined by spectrophotometry, and then more sterile water added, if necessary, to give a concentration of approximately $150 \mathrm{ng} \mathrm{\mu l}^{-1}$ DNA. Aliquots were then stored at $-20^{\circ} \mathrm{C}$. 
PCR for the detection of Pilchard herpesvirus. PHV PCR has been designed to amplify a region of PHV from ORF 62 of the genome, which is suggested to code for a putative terminase involved in DNA packaging, and amplifies a product of $373 \mathrm{bp}$. Standard reaction volumes were $25 \mu \mathrm{l}$, with the following components included in the PCR: $400 \mu \mathrm{M}$ each dNTP, $2.5 \mathrm{mM}$ $\mathrm{MgCl}_{2}, 0.5 \mu \mathrm{M}$ primer PHV373F 5'ACACATGATTTTGGATAAACTGGGG-3'，0.5 $\mathrm{MM}$ primer PHV367R 5'ATCTGGGTTGAAGATGAACCGCGCC-3', 0.1 U Tth Plus DNA Polymerase (Fisher Biotec), and $10 \times$ buffer at $1 / 10$ the volume of the PCR. Approximately $150 \mathrm{ng}$ of suitable template, such as partially purified virus or DNA extracted from infected tissue using the DNAzol methodology with slight modifications (Life Technologies), was added per $25 \mu \mathrm{l}$ reaction.

PCRs were performed on an MJ Research Minicycler (Geneworks), and cycle conditions were as follows: initial denaturation step of $96^{\circ} \mathrm{C}$ for $1 \mathrm{~min}$, then 30 cycles of $96^{\circ} \mathrm{C}$ for $30 \mathrm{~s}, 60^{\circ} \mathrm{C}$ for $45 \mathrm{~s}$, and $72^{\circ} \mathrm{C}$ for $1 \mathrm{~min}$, followed by a final extension at $72^{\circ} \mathrm{C}$ for $4 \mathrm{~min}$, then held at $14^{\circ} \mathrm{C}$.

PCR products were run with a 100 bp DNA ladder, Hyperladder IV (Bioline) on a $1.5 \%$ agarose gel (Progen) containing $0.5 \mathrm{mg} \mathrm{ml}^{-1}$ ethidium bromide at $90 \mathrm{~V}$ for $50 \mathrm{~min}$, and visualised by a UV transilluminator (Pathtech).

Freeze-squeeze method for extracting DNA from agarose gel. The following method is used at the State Agricultural and Biotechnology Centre, Murdoch University, Western Australia.

The PCR product was run on an agarose gel, the desired band cut out and placed in a $1.5 \mathrm{ml}$ microcentrifuge tube, and frozen immediately at $-20^{\circ} \mathrm{C}$ for at least $30 \mathrm{~min}$. The gel slice was squeezed between a parafilm sheet that had been folded in half, and all of the liquid that appeared as the gel slice thawed was extracted and placed in a sterile microcentrifuge tube. One tenth of the extract volume of $3 \mathrm{M}$ sodium acetate pH 5.2 and double the extract volume of $70 \%$ ice-cold ethanol were added, and gently agitated using a vortex mixer. The preparation was centrifuged at $10000 \times g$ for $5 \mathrm{~min}$, the supernatant discarded, and the pellet vacuum-dried. Then $12 \mu \mathrm{l}$ of sterile water was added to dissolve the pellet, and $5.75 \mu \mathrm{l}$ of this was used in a sequencing reaction.

Sequencing. DNA samples extracted using the modified DNAzol procedure were used to generate a PCR product suitable for sequencing. The methodology of the PHV373 PCR was followed, except that a high fidelity DNA polymerase, Accuzyme (Bioline), instead of a standard Taq polymerase, was used to ensure higher accuracy during amplification.

Then $8 \mu$ of the PCR product along with $1 \mu$ of loading dye (Progen) was run on a $1.5 \%$ agarose (Progen) gel containing $0.5 \mathrm{\mu g} \mathrm{ml}^{-1}$ ethidium bromide (Progen) and visualised using a UV transilluminator (Pathtech) to detect a product of about $373 \mathrm{bp}$ in size. If a primerdimer product was visible, as sometimes seen due to a low level of target DNA, the specific band at the $373 \mathrm{bp}$ mark was cut out of the agarose gel and extracted using the Freeze-Squeeze method, as described previously, with $5.75 \mu \mathrm{l}$ of the final solution used in a forward and a reverse sequencing reaction.

Sequencing was carried out at the State Agricultural and Biotechnology Centre, Murdoch University, Western Australia, Australia using the following procedure:

The ABI Prism ${ }^{\mathrm{TM}}$ Dye Terminator Cycle Sequencing Kit (Applied Biosystems) was used according to manufacturer's instructions, except that the reaction volumes were $10 \mu \mathrm{l}$ instead of $20 \mu \mathrm{l}$, and the annealing temperature was $55^{\circ} \mathrm{C}$, which was more suitable for the PHV primers. The sequencing reaction mix consisted of $3.25 \mu \mathrm{l}$ of Ultrapure Water (Fischer-Biotec), $4 \mu \mathrm{l}$ of DYE $\mathrm{T}$ mix (Tris- $\mathrm{HCl}_{i} \mathrm{MgCl}_{2}$ fluorescent labelled dATP, dCTP, dGTP, dTTP; dNTP and dITP, thermal stable pyrophosphatase and Amplitaq ${ }^{\circledR}$ DNA polymerase; Perkin Elmer, Australia), $0.25 \mu \mathrm{l}$ (3.2 pmol) of either PHV373F forward, or PHV367R reverse, primer at a

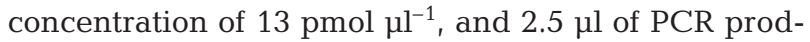
uct, to give a total reaction mixture of $10 \mu \mathrm{l}$. Cycle conditions were $96^{\circ} \mathrm{C}$ for $2 \mathrm{~min}$, followed by 30 cycles of $96^{\circ} \mathrm{C}$ for $20 \mathrm{~s}, 55^{\circ} \mathrm{C}$ for $10 \mathrm{~s}$ and $60^{\circ} \mathrm{C}$ for $4 \mathrm{~min}$.

When the sequencing reaction finished, $10 \mu \mathrm{l}$ of product was transferred to a $0.5 \mathrm{ml}$ microcentrifuge tube containing $25 \mu \mathrm{l}$ of ice-cold $100 \% \mathrm{v} / \mathrm{v}$ ethanol, $1 \mu \mathrm{l}$ of $125 \mathrm{mM}$ EDTA (Sigma) and $1 \mu \mathrm{l}$ of $3 \mathrm{M}$ sodium acetate $\mathrm{pH}$ 5.2. After gentle mixing, the tube was left on ice for exactly $20 \mathrm{~min}$ to precipitate the DNA before being centrifuged at $10000 \times g$ for $30 \mathrm{~min}$. The supernatant was discarded and the remaining pellet rinsed with $125 \mu \mathrm{l}$ of ice-cold $80 \% \mathrm{v} / \mathrm{v}$ ethanol. The sample was centrifuged at $10000 \times g$ for 5 min at ambient temperature, and the supernatant removed. The reaction products were dried under vacuum (Speedvac Concentrator, Savant). Interpretation of the sequencing reaction was performed using the 373 Automated DNA sequencing system (Applied Biosystems). Sequence data were edited using the SeqEd program, version 1.0.3 (Applied Biosystems).

\section{RESULTS}

The 373 bp fragment specific for PHV is shown in Fig. 1. It can be seen from Fig. 1 that the PHV373 PCR did not amplify PHV from DNA samples from fish collected pre- or post-outbreak, but consistently produced a specific band of the correct size (373 bp) for samples from fish collected in the midst of the epizootic. 
The sequence that was consistently obtained using the PCR product from the partially purified virus derived from fish in Western Australia (WA) in 1998 was used as the reference sequence. The sequence, $373 \mathrm{bp}$ in length including primers shown in bold lowercase, is consistent with initial sequence data previously described (Eaton et al. 2002), and is as follows:

acacatgattttggataaactggggTTGGCCACACCGGAGATTGCCGCACATAATCCCAAATGTGCATCACCCAGTACTGTGTTACAGATTGATAAAATTTTCACAAGATACAGTAAATGCTACTCGTTGGTTTTAGC CCCTCGACAATGTGGGAAGACCACCATCATGGTCTTATTGGTCGCCGCGATGATTCTTTACACGGATATGGACCTGGTGGTCCAAGCTCAAAA CATAAACATGTGTGAGCAAAACTTCAAGGGCGT TGTCGCGCTGATGGACGACATCATGGACGAGCCGACCTTCGAGAAGGAACACCGCTACACAAGAATGGTTGGTACCATGGAGGGggcgcggttcatctt caacccagat

PCR products from various tissue samples (Table 1) were used for obtaining sequence, and it was found that, out of 7 PCR products used for sequencing, only 1 showed variation from the consensus sequence (Table 1). The variation consisted of only 1 silent base change with the codon still coding for histidine. The reference sequence has been listed as Genbank Accession Number AY995177.

\section{DISCUSSION}

At the level of the deduced amino acid sequence it appears that the herpesvirus sequence from fish affected during the 1995 outbreak was identical to the PHV sequence from fish affected during the 1998 outbreak. However, this research involved analysis of only $373 \mathrm{bp}$ of the PHV and should be considered as preliminary only. The ORF 62 gene, which encodes a putative terminase and is thought to be involved in DNA packaging, appears to be highly conserved throughout the family Herpesviridae (Davison 1998), and therefore was useful for generating generic primers for obtaining the first sequence for PHV. There may be significant differences between the 1995 and 1998 PHV isolates in other parts of the genome.

Although these data allow only preliminary comparison of the 1995 and 1998 isolates, the PHV sequence of the ORF 62 gene is considerably different from that of other fish herpesviruses such as Ictalurid herpesvirus 1 (CCV) and Salmonid herpesvirus 2 (SaHV2), and has no significant similarity to mammalian or avian herpesviruses. The PHV sequence is most closely related to CCV and SaHV2, with 51\% similarity at the amino acid level. Not all fish her-

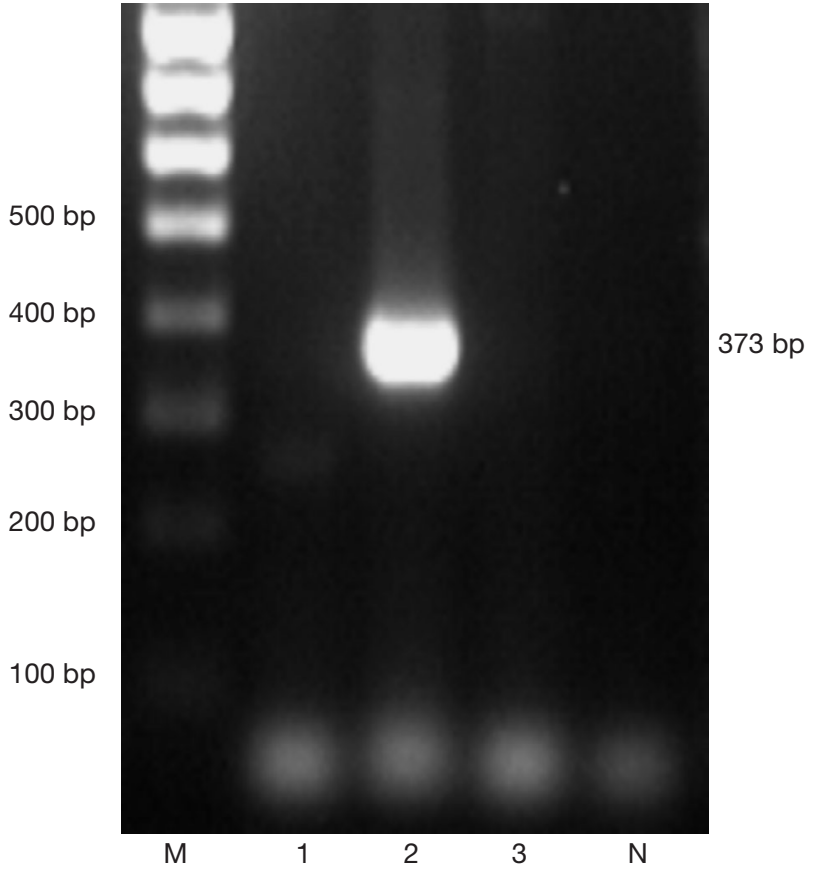

Fig. 1. Agarose gel electrophoresis photo of PCR product amplified by the PHV PCR protocol. M = 100 bp DNA Ladder Hyperladder IV (Bioline); Lane 1 = DNA sample from fish collected pre-outbreak, 1995 epizootic; Lane 2 = DNA sample from fish collected during 1995 epizootic; Lane $3=$ DNA sample from fish collected post-outbreak, 1995 epizootic; $\mathrm{N}$ = Negative control (PCR master mix and sterile water)

pesviruses have been sequenced over this region of the genome and therefore cannot yet be compared to PHV.

The $373 \mathrm{bp}$ fragment sequence of the ORF 62 of PHV appears to be sufficiently different from other fish herpesviruses that its detection would provide evidence of the presence of PHV. The fact that the region analysed is known to be highly conservative in herpesviruses suggests that PHV is indeed unique. Fish herpesviruses appear to be very different from mammalian and avian herpesviruses; for example, the genomic structure of $\mathrm{CCV}$ resulted in $\mathrm{CCV}$ being the only species (Ictalurid herpesvirus 1) in its own genus, Ictalurivirus, within the herpesvirus classification (Buchen-Osmond 2003). Although virion and capsid morphology in CCV and other herpesviruses are similar, comparison of CCV genes with other known herpesvirus genes suggests they are quite different phylogenetically (Kucuktas \& Brady 1999). Similarly, based on the current limited data, PHV appears to be related to other fish herpesviruses but bears no resemblance to mammalian or avian herpesviruses. Indeed, CCV and SaHV2 share only $61 \%$ similarity at the amino acid level over the ORF 62 region, indicating that, while the fish herpesviruses appear to be phylogenetically similar, they are still very different from one another. Recently, another fish virus, Koi herpesvirus 
(KHV), has been widely reported (Ronen et al. 2003, Hedrick et al. 2004, Way et al. 2004). Since the genome is larger than that of known herpesviruses and sequence data show little similarity to other herpesviruses (Ronen et al. 2003), some researchers prefer the designation Carp nephritis and gill necrosis virus (CNGV) for this virus due to doubt surrounding the virus classification. Sequence data have revealed that only small fragments (<50 base pairs) are similar to known viral genomes and, in particular, the thymidine kinase gene showed no similarity to other known herpesvirus thymidine kinase genes, suggesting that KHV/CNGV may represent a new species (Ronen et al. 2003). The classification of piscine herpesviruses clearly needs to be revisited (Hedrick et al. 2004, Way et al. 2004).

This paper has described a PCR for the detection of Pilchard herpesvirus. Our inability to culture this virus has slowed further research and characterisation of this virus (Hyatt et al. 1997, Eaton et al. 2002). For example, it is not known whether PHV behaves in a similar manner to other herpesviruses with respect to latency. If there is a latent phase it is clear that it cannot be detected using the current PCR. Development of diagnostic procedures, such as real-time PCR, for the detection of the latent phase of PHV would prove useful. An ability to detect the latent phase would assist in determining whether pilchard samples cryopreserved prior to 1995 contain PHV. This would also be useful for biosecurity applications such as the testing of imported pilchards for the detection of both non-latent and latent PHV. Clearly, there is also a need for more detailed comparison between viral sequence from the 1995 mortality and that from the 1998 mortality, preferably over a greater region than $373 \mathrm{bp}$ of conservative sequence. At the very least, there is a need for the development of rapid, sensitive tests to detect PHV in infected fish, and the results presented here have created a base from which to address this need.

Acknowledgements. The authors thank B. Eaton, H. Byers and K. McColl of the Australian Animal Health Laboratory, Geelong, Australia, and P. Hillier of the Department of Fisheries Western Australia, Australia, for their contributions to this work. The authors also acknowledge B. Chadwick, formerly of the Australian Animal Health Laboratory and Department of Fisheries Western Australia, for his significant involvement in the early Pilchard herpesvirus work.

\section{LITERATURE CITED}

Buchen-Osmond C (2003) The Universal Virus Database ICTVdB. Comput Sci Eng 5(3):16-25

Dann P, Norman FI, Cullen JM, Neira FJ, Chiaradia A (2000)

Editorial responsibility: Jo-Ann Leong,

Kaneohe, Hawaii, USA
Mortality and breeding failure of little penguins, Eudyptula minor, in Victoria, 1995-96, followed by a widespread mortality of pilchard, Sardinops sagax. Mar Freshw Res 51:355-362

Davison AJ (1998) The genome of salmonid herpesvirus 1. J Virol 72 (3):1974-1982

Eaton B, Byers H, Williams L, McColl K, and Crane M (2002) Generation of diagnostic reagents for Pilchard herpesvirus. Fisheries Research and Development Corporation, Final Rep 1999/226, Canberra

Fletcher WJ, Jones BJ, Pearce AF, Hosja W (1997) Environmental and biological aspects of the mass mortality of pilchards (autumn 1995) in Western Australia. Department of Fisheries of Western Australia, Perth, Fish Res Rep 106:1-115

Gaughan DJ, Mitchell RW, Blight SJ (2000) Impact of mortality, possibly due to herpesvirus, on pilchard Sardinops sagax stocks along the south coast of Western Australia in 1998-99. Mar Freshw Res 51:601-612

Gaut AC (2001) Pilchard (Sardinops sagax) mortality events in Australia and related world events. Fisheries Research and Development Corporation, Final Rep 1999/227, Canberra

Griffin DA, Thompson PA, Bax NJ, Bradford RW, Hallegraf GM (1997) The 1995 mass mortality of pilchard: no role found for physical or biological oceanographic factors in Australia. Mar Freshw Res 48:27-42

Hedrick RP, Gilad O, Yun SC, McDowell TS, Waltzek TB, Kelley GO, Adkison MA (2004) Initial isolation and characterization of a herpes-like virus (KHV) from koi. In: Denham K, Dixon P, Stone D, Way K (eds) Int Workshop on Koi Herpesvirus, London, 12-13 Feb 2004. Fisheries Resource Management, London, p 6

Hyatt AD, Hine PM, Jones JB, Whittington RJ, Kearns C, Wise TG, Crane MS, Williams LM (1997) Epizootic mortality in the pilchard Sardinops sagax neopilchardus in Australia and New Zealand in 1995. II. Identification of a herpesvirus within the gill epithelium. Dis Aquat Org 28:17-29

Jones JB, Hyatt AD, Hine PM, Whittington RJ, Griffin DA, Bax NJ (1997) Special topic review: Australasian pilchard mortalities. World J Microbiol Biotechnol 13:383-392

Kucuktas H, Brady Y (1999) Molecular biology of channel catfish virus. Aquaculture 172:147-161

Murray AG, O'Callaghan M, Jones B (2000) Modelling of the pilchard mass mortality events of 1995 and 1998/9. Fisheries Research and Development Corporation, Final Rep 1999/225, Canberra

Murray AG, O'Callaghan M, Jones B (2001) Simple models of massive epidemics of herpesvirus in Australian (and New Zealand) pilchards. Environ Int 27:243-248

Ronen A, Perelberg A, Abramowitz J, Hutoran M, Tinman S, Bejerano I, Steinitz M, Kotler M (2003) Efficient vaccine against the virus causing a lethal disease in cultured Cyprinus carpio. Vaccine 21:4677-4684

Way K, LeDeuff RM, Stone D, Denham KL, St-Hilaire S (2004) Koi herpesvirus: Diagnostics and research at CEFAS Weymouth laboratory 2000-2003. In: Denham K, Dixon P, Stone D, Way K (eds) Int Workshop on Koi Herpesvirus, London, 12-13 Feb 2004. Fisheries Resource Management Limited, London, p 9

Whittington RJ, Jones JB, Hine PM, Hyatt AD (1997) Epizootic mortality in the pilchard Sardinops sagax neopilchardus in Australia and New Zealand in 1995. I. Pathology and epizootiology. Dis Aquat Org 28:1-16

Submitted: January 12, 2005; Accepted: June 17, 2005

Proofs received from author(s): December 20, 2005 